\title{
A Lie for a Lie: MPLA Media Control in Ondjaki's Luandan Novels
}

\author{
James Hussar \\ California State University, Fullerton
}

\begin{abstract}
This essay analyzes the strategies used by Angolan author Ondjaki (Ndalu de Almeida, 1977- ) to critique the control of Angolan media by the nation's ruling party, the People's Movement for the Liberation of Angola (MPLA), in four novels: Bom Dia Camaradas (2001), Quantas Madrugadas Tem a Noite (2004), AvóDezanove e o Segredo do Soviético (2008), and Os Transparentes (2012). In the first three novels, Ondjaki draws on narrative techniques associated with oral storytelling and magical realism to create unreliable, exaggerated accounts, which he uses to discredit similarly hyperbolic "official histories" propagated by Angolan news outlets. In his latest novel, however, Ondjaki tackles collusion between the MPLA and the Angolan press more directly, detailing a process by which corrupt government officials and their media lackeys generate news releases in the interests of the Angolan elite and at the expense of the public.
\end{abstract}

Keywords: Ondjaki, Angolan fiction, Angolan media, MPLA, unreliable narrator, oral storytelling, magical realism.

\section{Introduction}

For Angolan author Ondjaki (Ndalu de Almeida, 1977- ), literature offers a forum to discuss his nation's "deepest wounds" (Martin and Moorman 42). Of his five novels, four take place in post-independence Angola, in the capital city of Luanda: Bom Dia Camaradas (2001), Quantas Madrugadas Tem a Noite (2004), AvóDezanove e o Segredo do Soviético (2008) and Os Transparentes (2012). ${ }^{1}$ The son of a former guerilla, vice-minister, and deputy (Martin and 
Moorman 61), Ondjaki imbues his fiction with political and social commentary. His nom de plume translates from Umbundu as "warrior" (Gonçalves), an allusion to his belief that "the pen is the pioneer's weapon" (Ondjaki, "Let's Share the Dream") and, more specifically, to his critical stance vis-à-vis the Movimento Popular de Libertação de Angola (MPLA), the nation's ruling party since 1975. The four Luandan novels, set against the backdrop of the country's seventeenyear civil war (1975-2002) between the MPLA and rival party, the União Nacional para a Independência Total de Angola (UNITA), lament the violence and its aftermath while also taking aim at government corruption and propagandism.

The present essay analyzes Ondjaki's criticism of the MPLA, in which his representation of state-controlled news outlets in Angola figures prominently. In the years following independence, the press became "an appendage of the government" (Oyebade 67). Today, the MPLA runs all media with nationwide reach, including the country's only daily newspaper, the Jornal de Angola, the Rádio Nacional de Angola (RNA), and Televisão Popular de Angola (TPA) (“Angola profile: Media"). The government stifles opposition by prosecuting its critics for defamation, a criminal offense punishable by fines and imprisonment. "Extra-official" measures of intimidation include harassment and physical attacks against dissenting journalists, contributing to a culture of self-censorship ("World Report 2011: Angola"). The MPLA muzzle on the media continued to tighten in anticipation of the August 31, 2012 legislative elections ("World Report 2012: Angola"), in which incumbent Jose Eduardo dos Santos emerged victorious.

In his first three Luandan novels, Ondjaki takes jabs at the MPLA by juxtaposing his narrators' unreliable, first-person accounts with descriptions of manufactured, government-sanctioned reports, subjecting both to scrutiny. His approach punctures all pretense of narrative authority, not only for the characters who double as his literary alter egos, but also for journalists under the MPLA's thumb. By intentionally undermining the voices closest to him, Ondjaki by extension manages to cast aspersions on official discourse propagated by Angola's ruling party.

My analysis of Ondjaki's use of unreliable narrators to critique MPLA media control in his first three Luandan novels takes into account two common 
themes in postcolonial African literary criticism. First, the analysis considers the role that oral storytelling techniques play in the novels by focusing on Ondjaki's first-person narrators and their admitted tendency to exaggerate and fabricate accounts. Second, it examines the relevance of recent theory on magical realism as it applies to Ondjaki's somewhat ironic portrayal of supernatural events in Angola. While acknowledging magical realism's well-documented limitations, I show that specific aspects of magical realist theory shed light on the strategies that Ondjaki uses to discredit official media reports and, by extension, the interests that they protect.

In Os Transparentes, Ondjaki dispenses with the somewhat roundabout critique characteristic of the earlier novels, instead leveling criticism directly against the MPLA and its media lackeys. Narrated in the third person with frequent use of dialogue, Os Transparentes describes the chasm separating the power elite and the "transparent" poor in contemporary Angola. The author portrays the government as an unconscionably corrupt and predatory institution whose officials exploit the less privileged in a series of money-grabbing schemes. Throughout the text, MPLA ministers treat the public with contempt as they initiate a dangerous plan to extract oil from Luanda, despite dire warnings from engineers consulting on the project. Rather than informing the public of the plan's risks, members of the media collude with government officials to silence critics and promote the economic interests of Angola's ruling class. Consequently, journalists share the blame for an apocalyptic fire that consumes the city. References to the growing presence and influence of the international press in Angola, however, offer a glimmer of hope for more open media discourse in the country in the future.

\section{Oral Storytelling Techniques in Ondjaki's Luandan Novels}

Together, Ondaki's four Luandan novels track Angola's post-revolutionary shift toward capitalism and the ongoing trauma related to the civil war over a period of more than two decades, from the late 1980s to the present. In spite of their serious subject matter, however, the novels evince a whimsical tone that derives in part from Ondjaki's use of oral storytelling techniques in his writing. Such transposition of oral traditions in written literature is common in Angola. 
As Ana Mafalda Leite notes, Angolan prose fiction since the mid-twentieth century has its matrix in oral cultures that stretch back at least 2,500 years (140), and several significant Angolan writers, including Pepetela, Raúl David, José Luandino Vieira, Joaquim Cordeiro da Matta, Óscar Ribas, António Jacinto, Henrique Abranches, and Rosário Marcelino, draw inspiration from oral traditions cultivated prior to the arrival of the Portuguese. Oral tradition also figures prominently in African novels outside Angola, such as Nigerian writer D.O Fagunwa's The Forest of a Thousand Demons (1938) and compatriot Amos Tutuola's The Palm-Wine Drunkard (1952) (Cooper, "Realism and magical realism" 460).

These precedents notwithstanding, Ondjaki downplays any connection between his fiction and precolonial African oral tradition, which he associates with rural environments and with the "mais velho da aldeia que conta histórias" (Henighan, "Uma entrevista com Ondjaki" 367). The author, however, cites the influence of what he terms "oratura urbana," and credits his grandmother, Agnette, whom he describes as a skilled storyteller, as an important source of inspiration for his work ("Re: Perguntas para um artigo"). AvóDezanove offers a glimpse of the formative relationship between Ondjaki and his grandmother, represented in the novel by the young, unnamed narrator and "AvóDezanove," respectively. As they walk together, AvóDezanove tells stories to her grandson, instructing him, "[Q]uando cresceres, tens que te lembrar de todas estas estórias. Dentro de ti. Prometes?” (88). Subsequently, the child's imagination becomes a depository for "os nomes e as casas e as pessoas todas da PraiaDoBispo" (AvóDezanove 118), the Luandan coastal community in which Ondjaki sets several of his stories and novels.

The "urban" brand of oral storytelling represents a central theme in Ondjaki's Luandan novels, as evidenced by metafictional passages in which characters reflect on strategies for telling their stories. In Bom Dias Camaradas, Ondjaki's namesake, Ndalu, and his classmates constantly critique one another's exaggerated accounts, and Ndalu's friend, Bruno, offers advice on how to stretch the truth without sacrificing believability: "quando queres baldar, balda só devagar, assim pode ser que vamos te acreditar!” (80; author's italics). Similarly, in AvóDezanove, the narrator and his friend, Pinduca, discuss the art of enhancing stories by making tweaks, or "adaptações," for the listener's pleasure 
(60). In Os Transparentes, journalist ArturArriscado, masquerading as fictitious military officer "CoronelHoffman," also attempts to regale his audience while keeping his artistic flourishes in check. When "Hoffman" pauses during a war story, the novel's third-person narrator describes his hesitation as the "momento professional de qualquer luandense quando se entrega a uma estória mais ou menos inverossímil, estudando se alguns dos presentes o vai desmascarar" (311). These characters convey Ondjaki's own self-consciousness about being "unmasked" as a storyteller, albeit by his readers rather than by a casual listener. In a 2006 interview, the author speaks to the aesthetic challenge of rendering the extraordinary events of his novels in believable ways, commenting that "tudo é possível, mas tem que ser bem feito, não se pode chegar aqui e dizer que uma casa levantou voo e esperar que todos acreditem" (Henighan, "Uma entrevista" 370).

Of the four Luandan novels, Quantas Madrugadas offers the most explicit references to storytelling. The narrator, a veteran traveler and modern-day Lazarus named AdolfoDido, expresses Ondjaki's theories on oral and written literature. He describes his novel-length conversation with a silent, unidentified interlocutor as "um acto artístico" (171), comparing his creative process to that of a potter molding clay (110). He also portrays storytelling as a collaborative process in which the listener participates: "Afinal não é só aquele que conta que conta: quem escuta calado também faz a estória” (188). In this sense, the relationship between AdolfoDido and his interlocutor resembles that of author and reader as portrayed in reader-response theory, a model that attributes a key role to the reader in the construction of the meaning of a text.

\section{Magical Realism in Ondjaki's Luandan Novels}

The oral traditions interpreted in novels by modern African writers often contain elements that defy explanation from a rational-empirical perspective. The recurrence of such elements, including myths, legends, folktales, and oneiric descriptions, no doubt contributes to the proliferation of critical analyses of African fiction in the context of "magical realism." This controversial literary term, which typically refers to the incorporation of seemingly supernatural incidents into otherwise realistic narratives, also denotes the presentation of 
elements of everyday reality as if they were incredible (Hegerfeldt 76). Coined by German art critic Franz Roh in 1925, the term "magical realism" gained currency in Spanish American literary criticism, first appearing in this context in Venezuelan writer Arturo Uslar Pietri's Letras y hombres de Venezuela (1948) (Leal 120), then entering the mainstream with the popularization of Latin American "boom" novels of the 1960s.

References to magical realism are commonplace in recent African literary criticism, particularly in studies of postcolonial fiction. Stephen M. Hart and Wen-chin Quyang argue that the Latin American brand of magical realism spread throughout the postcolonial world of the 1980s and 1990s because it "appeared to offer a literary idiom which could reflect the raw political tensions which accompanied the movement towards nationhood" (11). In the same vein, Lydie Moudileno calls magical realism an "arme miraculeuse" for the postcolonial African novel (29). More specifically, studies have explored the intertextual relationship between the "urtext" of Latin American magical realism, Colombian author Gabriel García Márquez’s Cien años de soledad (1967), and African postcolonial novels such as Malian author Yambo Ouologuem's Le devoir de violence (1968) and Sierra Leonenan author Syl Cheney-Coker's The Last Harmattan of Alusine Dunbar (1990). ${ }^{2}$

Despite its widespread use as a premise for literary analysis, magical realism remains a polemical if not polarizing concept among critics. Much of the debate centers on the authenticity, or lack thereof, of the portrayal of the "Other" in magical realist texts. While some hail magical realism as an international movement that gives voice to the margins, others characterize it as a form of "aesthetic colonization" that essentializes and commodifies "native" perspectives and practices (Faris 104). As Stephen Slemon notes, many purportedly "ex-centric" writers in the mode have entered the mainstream, where they "find a ready market for the recirculation of what the imperial center takes to comprise the 'characteristic' literary and cultural forms of formerly colonized cultures" (408). It could be argued that Ondjaki fits this description, considering that Lisbon-based Editorial Caminho publishes and distributes his works.

In postcolonial Angola, ties between literature and politics further complicate the possibility of writing from the margins. Several of Angola's most 
important writers, including Agostinho Neto, José Luandino Vieira, Pepetela and Manuel Rui, have held prominent positions in the MPLA. Moreover, the government sponsors prose and poetry awards including the Prémio Nacional de Literatura and the Prémio Alda Lara (Oyebade 59). As Anne Hegerfeldt observes, such proximity to the "cultural center" not only undermines the magical realist author's ability to speak as "Other," but also neutralizes the mode's "subversive capacity" (63).

The above objections notwithstanding, magical realism merits consideration when analyzing Ondjaki's Luandan novels, given the nature of the characters and events that he describes therein. In a 2010 interview, Ondjaki calls Luanda a "surrealistic city" where everyday life plays out in "crazy and fantastical episodes" (Martin and Moorman 50). Accordingly, the Luanda of the novels is an inherently magical place where the dead commingle with the living, rainfall of biblical proportions floods the streets, human beings interact with swarms of bees, alligators, demonic dogs, and sea monsters, and the poor experience transparence and weightlessness.

Ondjaki's characters tend to accept such extraordinary phenomena as part and parcel of life in Angola. Their attitude is characteristic of narrators of magical realist texts, who, as Ato Quayson asserts, "must not pass judgment on the magical in order to suggest an ethical or other hierarchy between that and the code of the real" (164). Ondjaki's narrators echo the author's comments about Luanda, offering blanket statements attesting to the city's marvelous qualities. In Bom Dia Camaradas, Ndalu remarks that "em Luanda, não se pode duvidar das estórias, há muita coisa que pode acontecer e há muita coisa que, se não pode, arranja-se uma maneira de ela acontecer" (106). The narrator of AvóDezanove expresses the same sentiment, explaining that "em Luanda tudo podia mesmo acontecer de repentemente" (9). Likewise, in Quantas Madrugadas, AdolfoDido compares everyday reality in Luanda to a soap opera (81) and comments that life is "mais mágica que o imaginado" (182).

Although Os Tranparentes uses third-person rather than first-person narration, dialogue in the text registers the characters' credence in Angola's magical reality. The novel's protagonist, Odonato, downplays his transformation into a transparent, weightless being, remarking, "é uma condição natural 
que me está a acontecer" (187). ${ }^{3}$ Elsewhere, local bartender Noé comments that "há coisas que ultrapassam o lado científico," leading to a conversation among the bar patrons about how Chinese women in Angola use a special potion to reduce the length of their pregnancies from nine months to six (301). In some cases, characters show a predisposition toward magical explanations of unusual incidents or situations. For example, the incredible weight of the corpse of Odonato's son, CienteDoGrã, prompts his former neighbor, CamaradaMudo, to suspect witchcraft: "é feitiço ou quê?" (341). Similarly, brothel matron AvóTeta asks if an impending solar eclipse is "coisa de deus ou feitiço dos americanos?" (109).

In his novels, Ondjaki relies on narrative techniques often associated with magical realism to portray Luanda as a "surrealistic city." One such technique is exaggeration, mentioned above and analyzed in relationship to unreliable narration below. Another is "literalization," which occurs when a phenomenon in a text owes its supernatural quality to "a movement from the abstract to the concrete, from the figurative to the literal, from the word to the thing" (Hegerfeldt 68). In this vein, Odonato's condition in Os Transparentes derives from a literalization of the metonymic relationship between "transparency" and "poverty," which Odonato explains matter-of-factly: "nós somos transparentes porque somos pobres" (203). Similarly, the weight of CienteDoGrãs corpse literalizes a metaphor uttered in Umbundu by AvóKunjikise: "pesado na vida e pesado na morte" (342; author's italics). Furthermore, CienteDoGrãs vow to his father, "nem morto volto para a tua casa" (340), takes on literal meaning when the weight of the corpse prevents Odonato from holding a wake for his son in his apartment.

A third technique common in magical realist texts involves the use of journalistic detail in hyperbolic accounts. In his analysis of García Márquez’s Cien años de soledad, Stephen Hart observes that the Colombian author's attention to detail lends "a sheen of verisimilitude" to over-the-top portions of the novel (45). A passage from Bom Dia Camaradas, in which Ndalu painstakingly describes a neighbor's insatiable appetite, illustrates this same effect:

Papí serviu-se sete vezes consecutivas sem direito a intervalo, mamou vinte e quatro bifes panados, pôs trinta e uma colheradas de arroz branco no 
prato (as minhas irmãs contaram), bebeu duas latas de coca-cola e, quando a minha mãe lhe disse que não havia mais, ainda conseguiu abater um litro e meio de água. (121-22)

Although Ndalu pushes the bounds of credulity, his mention of details, including specific menu items and the number of servings of each, all of which are corroborated by his sisters, suggests an accurate representation of Papís orgiastic feast. ${ }^{4}$

4. Discrediting the Magic: Unreliable Narration and Allegory in Ondjaki's Luandan Novels

Although Ondjaki's public comments corroborate the views expressed by his storytellers, it is the relationship between the perspective of the narrator and that of another agent, the "implied author," that determines the reliability of a text. Wayne C. Booth describes the implied author as the author's "second self," an intermediary between the author and narrator (151). When a narrator's account differs from that which the implied author would offer, the former is considered unreliable (Phelan 49). In Ondjakis first three Luandan novels, the implied authors offer clues intended to discredit the narrators' magic-imbued accounts, thus casting doubt on their reliability. These clues include references to suspect second-hand reporting, frequent admission of exaggeration on the part of the narrators, overzealous claims of trustworthiness on the part of the narrators, and the inclusion of logical explanations for purportedly supernatural occurrences. In Os Transparentes, Ondaki's implied author takes a different tack, indicating that supernatural occurrences are meant to be read allegorically rather than as affirmations of Angola's "magical reality."

As William Riggan argues, first-person narrators are unreliable by nature because of limitations with respect to their knowledge, judgment and memory (19). These factors come into play in Ondjaki's first three Luandan novels, often at critical junctures. In Bom Dia Camaradas, Ndalu offers disclaimers stating that he hasn't seen what he reports, including a supposed attack on his school by a guerrilla group known as Caixão Vazio $(76,89)$. His account of the novel's climax cobbles together the equally compromised testimony of several classmates 
(85-89, 100-105). In AvóDezanove, the narrator punctuates his description of the explosion of a mausoleum dedicated to the country's deceased president, Agostinho Neto, with the refrain "nós não vimos," repeated five times (179-81). Like Ndalu, he relays second-hand information, in this case provided by his neighbors. In Quantas Madrugadas, much of AdolfoDido's alcohol-soaked story rehashes his friends' accounts, as most of the events in the novel take place following his death and prior to his resurrection. Moreover, AdolfoDido acknowledges his mental fatigue and the difficulty with which he recalls details, although these admissions might be read as a ploy to coax another drink from his interlocutor $(46,116)$.

In addition to acknowledging their limitations, Ondjaki's first-person narrators also readily admit to substantial creative license when storytelling. In Bom Dia Camaradas, Ndalu depicts exaggeration as endemic to Luanda, remarking that "toda a gente que eu conheço aqui em Luanda aumenta estórias" (79). Accordingly, he and his friends regularly engage in rounds of verbal one-upmanship when telling stories, with each child embellishing or inventing details in an attempt to outdo the others. Similarly, in AvóDezanove, the narrator expresses his preference for fabricated stories, commenting, "As estórias boas de contar são as que nós inventamos" (159). In Quantas Madrugadas, AdolfoDido, referring to himself in the third person, also discloses his tendency to present fiction as fact: "ele não é nada das coragens, mesmo estórias ele conta militares, tudo então pura ficção, estórias bem verídicas, como ele gostava de dizer" (21; author's italics). This veiled admission prompts the reader to reevaluate the narrative retroactively, after AdolfoDido reveals his identity toward the end of the novel.

Despite the clear markers of unreliability described above, Ondjaki's firstperson narrators issue emphatic guarantees of their trustworthiness. In Bom Dia Camaradas, Ndalu introduces his description of Papí by solemnly swearing on his grandfather's soul not to exaggerate (121). Similarly, the narrator of AvóDezanove explains that his account of the mausoleum explosion derives from years of carefully compiling eyewitness testimony (179). AdolfoDido also makes truth claims throughout Quantas Madrugadas, repeatedly assuring his immediate interlocutor, and by extension the reader, that his stories 
are "puramente verídicas, nenhumas ficções" (137). The three storytellers conform to Ondjaki's general view of Luandans, who, according to the author, "are always trying to find an excuse to tell you a story, and that story doesn't have to be real. But they will swear it's real" (Martin and Moorman 51).

Ironically, the narrators' frequent appeals to ethos also suggest their unreliability. In her analysis of self-conscious narrators in magical realist texts, Hegerfeldt observes that such storytellers "generate the feeling that they are putting the reader on-mainly because they protest too much that that is not what they are doing, by no means, not at all" (67; author's italics). Consequently, their zealous truth claims backfire, prompting the reader to treat their texts with skepticism.

For Richard Walsh, unreliable texts must have an internal logic or explanation related to the psychology of the narrator (79). Accordingly, in Ondjaki's novels, first-person narrators resort to exaggeration and magical realism not only to entertain, but also to mitigate potentially shameful or painful situations. In AvóDezanove, a young housekeeper's promiscuous seaside rendezvous prompt her neighbor, EspumaDoMar, to comment, "Ainda aparece com a barriga redonda, vão falar que foi o mar" (55). The comment sheds light on an earlier passage in the novel in which the narrator recalls CarmenFernandez, a family friend whose two pregnancies had ended strangely. The woman "tinha ficado grávida uma vez mas tinha parido um enorme saco de formigas que lhe picavam dentro da barriga, a segunda vez que ficou grávida acabou por ter um bebé, mas que tinha cabeça e asas de pássaro e, como a janela estava aberta, fugiu a voar" (30). By establishing the potential use of local legend to cover up the housekeeper's behavior, Ondjaki hints that the supernatural stories surrounding the results of CarmenFernandez's pregnancies mask a more mundane, and perhaps painful or socially unacceptable, reality. Another such "reality check" appears in Quantas Madrugadas, when AdolfoDido presents two explanations for the sudden disappearance of cars in Luanda: either they have been dragged away by Kianda, the Water God, or simply stolen by thieves (130-31).

On the same note, the creation of magical stories offers Ondjaki's narrators a means of coping with Angola's tragic civil war. As Fernando Arenas observes, the novels express an "intense desire for enduring peace" (172). The characters, 
however, greet news of national reconciliation with skepticism. In Bom Dia Camaradas, a doubtful Ndalu responds to reports of negotiations by asking, "Há quantos anos é que ouves essa conversa?" (118). Likewise, Pinduca remarks in AvóDezanove, "É que tão toda a hora a falar na paz, mas que eu saiba a paz ainda não existe" (64). In Quantas Madrugadas, AdolfoDido’s trepidation about "as hipóteses todas da paz" (192) dampens his optimism, reflecting what Ondjaki calls "uma espécie de incerteza" with regard to Angola’s future (Henighan, "Uma entrevista" 369).

Os Transparentes, set a decade after the cease-fire, registers the profound lingering effects of the conflict, characterizing the civil war as a ubiquitous "fantasma" (208), "a ferida nacional" (208-209), and "uma lembrança sempre a sangrar" (209). For Angolans in the novel, the civil war's legacy equates to living with the constant fear that armed conflict will resume, as illustrated in a pair of key passages. The text notes a sense of dread following the President's call for two national days of remembrance: "houve quem julgasse tratar-se do reacender do conflito armado" (330). Later, explosions resulting from the citywide fire prompt an unnamed elderly woman to shout, "ai, meu deus, começou outra guerra" (411). In light of the ongoing psychological trauma caused by the civil war, magical realism in Ondjaki's novels may represent more than escapist fare. By insisting on the potential for magic in Angola, Ondjaki's narrators also spur hope for an otherwise unfathomable miracle, namely, a definitive end to the violence that divided the nation for nearly three decades.

Os Transparentes, however, marks a departure from the other Luandan novels in that Ondjaki uses magical events to allegorize social and political problems in Angola rather than to depict the country's purportedly magical reality. He clearly establishes Odonato as an archetype of Angola's poor, with the protagonist declaring, "eu sou parte deste povo! do povo angolano, o povo...conhecem essa palavra? é uma palavra cheia de gente!" (144). Odonato identifies the source of his suffering as the "doença de mal-estar nacional" (179), which he directly links to his physical state: "este é o meu corpo, esta é a visão da minha dor" (268). Noting that "a transparência é um símbolo" (283), Odonato also relates his condition to that of Luanda’s less privileged: "há alguns que são transparentes. acho que a cidade fala pelo meu corpo" (284). 
The root cause of Odonato's transformation and, by extension, Angola's ills, appears to be the country's conversion to capitalism in the years following independence. As Arenas (182) and Phillip Rothwell (245) note, Ondjakis earlier novels lament the nation's economic and ideological shift, which is portrayed symbolically through the departure of Cuban teachers, doctors and soldiers in Bom Dia Camaradas, and of Russian armed forces in AvóDezanove. In Os Transparentes, Ondjaki once again turns to allegory, personifying the hopes of socialist Angola as "a senhora Ideologia." Soon after internationally financed oil extraction begins in Luanda, death befalls "a senhora," casting a pall across the city:

\begin{abstract}
invadida por um torpor, com a exceção dos trabalhadores cipelinos, a cidade parecia evacuada, o silêncio nas casas era interrompido pelos rádios ou aparelhagens tristes, as crianças pareciam inibidas nas suas vontades de brincar, os cães encheram os olhos de uma tristeza mais aguda em homenagem ao falecimento prematuro da senhora Ideologia. (341)
\end{abstract}

The passage describes two different reactions to Senhora Ideologia's death. The public at large mourns, their plight suggestive of stalled progress and sorrow that can be attributed to the MPLA's betrayal of its founding principles. On the other hand, those affiliated with the government, including oil workers and broadcasters, behave callously, undeterred by the pain that surrounds them.

\title{
5. Putting the "Press" in Repression: MPLA Media Control in Ondjaki's Novels
}

Unreliability in Ondjaki's Luandan novels relates not only to the narrators' limitations, artistic aspirations, or psyches, but also to the author's critical position with respect to the MPLA and its institutionalization of the news media. In Bom Dia Camaradas, AvóDezanove and Quantas Madrugadas, Ondjaki exposes and satirizes the role that the state-run press plays in the MPLA's consolidation of power. As a source of information, the Angolan press portrayed in the novels shares some of the same shortcomings as Ondjaki's unreliable narrators, including a lack of knowledge and a tendency to fabricate stories. Consequently, the 
author's dismantling of his narrators and their pretense of authority transfers seamlessly to the government media outlets that make the same claim.

The government's ubiquitous presence and control of access to information represent recurring themes in Bom Dia Camaradas. Ondjaki describes a police-state atmosphere in which the Forças Armadas Populares de Libertação de Angola (FAPLA), the military wing of the MPLA, carry out abuses in the name of security. While in the airport to pick up his visiting Portuguese aunt, Ndalu witnesses a FAPLA officer confiscating a tourist's camera and destroying its contents "por razões de segurança de Estado" (38). Later, Ndalu fears being shot by FAPLA forces when his unwitting aunt fails to follow proper protocol as a presidential motorcade passes (53).

In the novel, the MPLA extends its reach from public spaces into the home through Rádio Nacional broadcasts. Ndalu's family plays radios in the living room and kitchen throughout the day and listens to the news regularly, even though the content and format of the reports are repetitive (25-26). Ondjaki takes a jab at the weak integrity of state-sanctioned radio programming by associating it with a child's exaggerations: when Bruno claims to have the "full story" of the Caixão Vazio episode, the narrator responds, "Eu sei o que é a versão integral, Bruno. Isso dá no noticiário todos dias” (100; author’s italics). The extent of MPLA media control appears when Ndalu and other schoolchildren receive invitations to read their student essays on the air during a special Labor Day broadcast. Upon arriving to the station, the children are handed ghostwritten radio messages, stamped with a government seal (36-37). Official discourse is contested, however, by the novel's description of the underfunded holiday demonstrations, which lack the traditional floats and refreshments because of the country's economic woes. A disillusioned Ndalu, anticipating the author's critical stance toward the MPLA, rejects the government's version of events and vows to tell the truth in his own words, remarking, "[N]ão quero saber lá da folha carimbada que já vem com tudo escrito" (84).

In AvóDezanove, Ondjaki satirizes the MPLA's attempts at social control through the media by having the narrator's pet parrots mimic the government slogans that they hear repeated on radio and television broadcasts, including "um só povo, uma só nação" (46) and "abaixo o imperialismo americano" (161). 
He also targets state oversight of the national newspaper with Pinduca's ironic remark, "Achas que o JornalDeAngola anda mesmo a pôr notícias de mentira? Seu burro, tudo o que sai no JornalDeAngola são verdades que o camarada presidente é que autoriza a saírem lá" (107). Earlier in the novel, Ondjaki calls the worth of the Jornal de Angola into question when the narrator and Pinduca discuss using pages from the newspaper as a substitute for toilet paper (60).

Compared to Bom Dia Camaradas and AvóDezanove, Quantas Madrugadas offers a more explicit and sustained critique of Angolan journalism. One of the novel's main characters, the albino Jaí, reads the newspaper regularly, establishing a pretext for Ondjaki's skewering of the Jornal. AdolfoDido makes a telling comment about the accuracy of the press by favorably comparing his own convoluted storytelling technique to newspaper reporting: "Tenho a coisa toda num fio só, num falo nada por acaso aqui: nem mesmo o jornal” (75). Throughout the text, similar hollow assurances of reliability serve as reminders of the newspaper's tendency to fabricate stories, which is further evidenced by its coverage of AdolfoDido's death and the controversy that ensues.

In the novel, the neer-do-well narrator and his mistress, KiBebucha, concoct a scheme to steal a government pension intended for military veterans, despite the fact that AdolfoDido has never served in the armed forces. When AdolfoDido unexpectedly dies, the Jornal de Angola propagates his false claim, creating a media circus around KiBebucha and DonaDivina, a second widow with an eye on the pension. Through his narrator, AdolfoDido, Ondjaki criticizes the press corps for failing to conduct adequate research prior to running their stories: "O Jornal de Angola fez mesmo a pura reportagem, duas páginas e meia, do pouco que se sabia e do muito que se especulava" (126). As the reaction of AdolfoDido's dumbfounded friends shows, the newspaper coverage defies both logical explanation and simple facts: in addition to being too young to have fought, AdolfoDido is reported to have participated in battles in the Namibe province, where armed conflict never took place (90-91).

While cursory investigative reporting explains some of the inaccuracies that appear in print, others are the deliberate result of government corruption. KiBebucha explains how she and AdolfoDido had purchased official documentation certifying the latter's military record, remarking that "o dinheiro faz 
a guerra até onde ela num devia ser feita" (91). Subsequently, she bribes the police to corroborate her lies in the press, in order to influence public opinion in her favor (126). Not to be outdone, DonaDivina tries to take advantage of the media attention to the case to reclaim her status as a member of Luanda's social elite $(86,125)$. The rivalry between the widows causes such chaos that the judge charged with resolving AdolfoDido's case bans journalists from attending the proceedings $(86,99)$. In the meantime, AdolfoDido's corpse, which Henighan ("The Quest for Angolanidade") and Arenas (179) associate with the national project under the MPLA, rots beneath a honey balm and an Angolan flag.

Of the four Luandan novels, Os Transparentes offers the most direct indictment of the collusion between the Angolan press and the MPLA, detailing corruption and media manipulation by the President and other high-ranking officials. The novel features three characters who are journalists: state newspaper reporter PauloPausado, Rádio Nacional reporter ManRiscas (also known as ArturArriscado and CoronelHoffman), and an unnamed BBC reporter on assignment in Angola. Through PauloPausado and ManRiscas, Ondjaki addresses the restrictions placed on Angolan journalists by the government. Cognizant of his newspaper's "compromissos com membros da alta esfera do Partido" (83), PauloPausado faces the challenge of covering a series of political scandals without running afoul of the Angolan elite. He prefaces his request for an official statement on a citywide water shortage by assuring Minister DomCristalino's aide, SantosPrancha, that he and his editor are "dispostos a colaborar" (99). This willingness to "play ball" derives not only from PauloPausado's awareness of the unlikelihood of obtaining information by any other means, but also from his fear of the consequences of portraying the MPLA unfavorably in the press.

The government's use of intimidation to coerce journalists is referenced in a telephone conversation in which PauloPausado and ManRiscas discuss MPLA involvement in a scheme to extract oil in Luanda. After confirming that the telephone line is secure, ManRiscas alludes to the extent to which the MPLA controls the dissemination of information in the national media: "todos que estivemos nessa reunião fomos ameaçados. qualquer coisa que saia nos jornais, fomos nós. eu nunca te disse nada. só te falei do que já está na boataria geral" (91). The hesitation and fear evident in ManRiscas's remarks are shared 
by PauloPausado as he prepares to interview DomCristalino. Wary of reprisal, the journal contemplates "até onde iria a benevolência de DomCristalino caso as suas perguntas fossem honestas e incómodas?” (167).

In the novel, the MPLA uses the same heavy-handed techniques to attempt to squash leaks to the international press. Raago, an American engineer hired by the Angolan government to rubber-stamp the oil extraction plan, is warned not to talk with members of the media without prior consultation with the Ministry (176). His studies of the plan, which prophetically point out a considerable risk to public safety, contradict the President's announcement that oil extraction in Luanda "era em prol do bem-estar da cidade e do país" (171). Consequently, Raago's troubling reports are buried and he is threatened with arrest (308).

Like Raago, the unnamed $\mathrm{BBC}$ reporter also falls prey to government intimidation when a pair of corrupt officials interrogates her about her credentials and documentation (225-28). During their verbal exchange, however, the witty reporter gets the better of the officials, and the failure of the attempted shakedown suggests cracks in the MPLA's hegemonic control of the media in Angola. In the same vein, the novel's repeated references to rooftop satellites that "apanham notícias e vozes de outros lugares mais internacionais" (52) indicate the increasing difficulty of repressing information in the digital age, an idea that is underscored when PauloPausado first learns of the oil extraction plan through a BBC broadcast (84). Through these examples, the independent, international press emerges as a potential ally in Ondjaki's efforts to undermine the MPLA's control of Angolan media.

\section{Conclusion}

Ondjaki's four Luandan novels document the development of the author's critique of the MPLA and its institutionalization of the Angolan press, with Os Transparentes marking a definitive shift in tone and tack from the earlier texts. In the first three novels, Ondjaki's nuanced and multilayered critique hinges on the relationship between, on one hand, the exaggerated and supernatural accounts of the texts' unreliable, first person narrators, and on the other, the "official" yet equally dubious newspaper, radio and television reports portrayed in the fiction. Although the narrators repeatedly insist on their truthfulness, Ondjaki distances 
himself from them through the use of an implied author who sows seeds of doubt in the narratives, as evidenced by the novels' registering of instances of storytellers readily admitting to exaggeration, embellishing for artistic purposes, and resorting to the use of legend to mask painful but otherwise explicable realities.

By undermining his own narrators, Ondjaki discredits other purportedly authoritative voices, specifically, Angola's print and broadcast media, which have been under tightening MPLA control since the country's independence. As sources of information, storytellers and journalists in Ondjaki's Luanda share some of the same weaknesses, including the tendency to compensate for gaps in their knowledge by presenting fiction as fact. Consequently, the government's seal, whether visible as on AdolfoDido's falsified documents or implied through state control of the press, becomes a symbol of fraud and corruption, rather than a guarantee of authenticity.

In Os Transparentes, Ondjaki forgoes the strategy of corroborating and subsequently debunking his narrators' magical realist accounts as a means of casting aspersions on MPLA-sanctioned press reports. Instead, he opts for a more direct indictment of the MPLA and its media practices, bluntly accusing high-ranking officials, most notably the President, of corruption and media manipulation, and laying the blame for the novel's climatic fire on the government's leaders and, by extension, the journalists that they coerce into misleading the public. As in the earlier novels, supernatural events still figure prominently in Os Transparentes, with Odonato's transformation into a transparent, weightless being serving as the text's primary plot line. Nevertheless Ondjaki's use of such events to allegorize Angola's social and political strife, rather than to affirm Angola's purportedly "magical reality," indicates a new direction in his fiction.

Notwithstanding the differences between the four Luandan novels, each evidences Ondjaki's use of techniques associated with oral storytelling and magical realism to reflect not only Angola's problems, but also its wonders. Perhaps the real magic of the novels resides in Ondjaki's ability to convey his profound optimism for the future of Angola, even as he matches the MPLAsanctioned media lie for lie. As EspumaDoMar of AvóDezanove remarks, "[A]s palavras têm encanto de magia e forças do invisível” (76). Seldom has an author so skillfully said "Abracadabra." 


\section{Notes}

1 Another novel, O Assobiador (2002), takes place in an imaginary village evocative of Luanda (Henighan, "Uma entrevista com Ondjaki" 367).

2 See Aizenberg (1992) and Cooper (1998), respectively.

3 In Os Transparentes, Ondjaki uses lowercase to begin sentences, capitalizing only proper nouns throughout the novel. As in his earlier novels, he also omits spaces in the names of people and places.

4 In an email, Ondjaki assured me that his description of Papí, a character based on an acquaintance of the same name, is true-to-life save for one minor detail: "não é verdade que bebeu duas coca colas porque a minha mãe nunca dava DUAS coca colas a uma só pessoa, este é o único exagero desta descrição" ("Re: Perguntas para um artigo"; author’s capitalization).

\section{Works Cited}

Aizenberg, Edna. "Historical Subversion and Violence of Representation in García Márquez and Ouologuem." PMLA 107.5 (1992): 1235-52. Print.

"Angola profile: Media." BBC News Africa. BBC, 11 April 2011. Web. 5 June 2012.

Arenas, Fernando. Lusophone Africa: Beyond Independence. Minneapolis: University of Minnesota Press, 2011. Print.

Booth, Wayne C. The Rhetoric of Fiction. Chicago: University of Chicago Press, 1961. Print.

Cooper, Brenda. Magical Realism in West African Fiction: Seeing with a Third Eye. New York: Routledge, 1998. Print.

"Realism and magical realism." Encyclopedia of African Literature. Ed. Simon Gikandi. New York: Routledge, 2003. 458-61. Print.

Faris, Wendy B. "The Question of the Other: Cultural Critiques of Magical Realism." Janus Head 5.2 (2002): 101-19. Print.

Gonçalves, Adelto. “Ondjaki: a reinvenção da linguagem.” Via Política: livre informação e cultura. Laser Press Comunicação, 31 Aug. 2008. Web. 10 Jan. 2010.

Hart, Stephen. "Magical Realism in Gabriel García Márquez’s Cien años de soledad." Inti: Revista de Cultura Hispánica 16-17 (September 1982): 37-52. Print.

Hart, Stephen M. and Wen-chin Ouyang. "Introduction. Globalization of Magical Realism: New Politics of Aesthetics." A Companion to Magical Realism. Ed. Stephen M. Hart and Wen-chin Ouyang. Woodbridge, UK: Tamesis, 2005. 1-22. Print.

Hegerfeldt, Anne. "Contentious Contributions: Magic Realism Goes British." Janus Head 5.2 (2002): 62-86. Print.

Henighan, Stephen. “The Quest for Angolanidade." Stephen Henighan. Web. 5 June 2012.

__. "Uma entrevista com Ondjaki." Hispanic Research Journal 7.4 (December 2006): 365-71. Print.

Leal, Luis. "Magical Realism in Spanish American Literature." Trans. Wendy B. Faris. Magical Realism: Theory, History, Community. Ed. Lois Parkinson Zamora and Wendy B. Faris. Durham: Duke University Press, 1995. 119-24. Print. 
Leite, Ana Mafalda. "Angola." The Post-Colonial Literature of Lusophone Africa." Ed. Patrick Chabal. Evanston, IL: Northwestern University Press, 1996. 103-64. Print.

Martin, Michael T., and Marissa J. Moorman. "Imagining Angola in Luanda with Ondjaki (Ndalu Almeida)." Black Camera 1.2 (2010): 38-62. Print.

Moudileno, Lydie. "Magical Realism: 'Arme miraculeuse' for the African Novel?" Research in African Literatures 37.1 (2006): 28-41. Print.

Ondjaki. AvóDezanove e o Segredo do Soviético. Lisbon: Caminho, 2008. Print.

—. Bom Dia Camaradas. Lisbon: Caminho, 2003. Print.

—. "Let's Share the Dream: Stories for Children in Angola." International Board on Books for Young People, n.d. Web. 29 April 2013.

—. O Assobiador. Lisbon: Caminho, 2002. Print.

- Os Transparentes. Lisbon: Caminho, 2012. Print.

—. Quantas Madrugadas Tem a Noite. Lisbon: Caminho, 2004. Print.

. "Re: Perguntas para um artigo." Message to the author. 2 Feb. 2010. E-mail.

Oyebade, Adebayo O. Culture and Customs of Angola. Westport, CT: Greenwood Press, 2007. Print.

Phelan, James. Living to Tell About It. Ithaca: Cornell UP, 2005. Print.

Quayson, Ato. "Magical Realism and the African Novel." The Cambridge Companion to the African Novel. Ed. F. Abiola Irele. Cambridge: Cambridge University Press, 2009. 15976. Print.

Riggan, William. Pícaros, Madmen, Naïfs, and Clowns: The Unreliable First-Person Narrator. Norman, OK: University of Oklahoma Press, 1981. Print.

Rothwell, Phillip. "The Authenticity of Smell: Contenting Civilization in the Angola of Ondjaki's Bom Dia Camaradas." Bulletin of Hispanic Studies 83.3 (2006): 241-48. Print.

Slemon, Stephen. "Magical Realism as Postcolonial Discourse." Magical Realism: Theory, History, Community. Ed. Lois Parkinson Zamora and Wendy B. Faris. Durham: Duke University Press, 1995. 407-26. Print.

Walsh, Richard. The Rhetoric of Fictionality: Narrative Theory and the Idea of Fiction. Columbus, OH: The Ohio State University Press, 2007. Print.

“World Report 2011: Angola." Human Rights Watch. Web. 5 June 2012.

"World Report 2012: Angola." Human Rights Watch. Web. 5 June 2012.

James Hussar is Associate Professor of Spanish and Portuguese at California State University, Fullerton.

His research interests include Jewish themes in Spanish, Spanish American and Luso-Brazilian literature. He received a $\mathrm{PhD}$ in Literature from the University of Notre Dame. 